\title{
PROFESSOR GINOSSAR'S REJOINDER
}

Having rapidly perused Professor Levontin's biting comments, I have discovered that most of his arguments have already been adequately disposed of in my article. There remain some objections, new but so evidently groundless, that I take this opportunity to rebut them. For the sake of brevity I will limit my counternote to generalities.

\section{Obligatory Rights}

Lévontin concedes that these rights are "almost as well protected as are rights of property" and that they are "universal' in the sense that no one is permitted to interfere with [them]". Yet he ridicules my "treatment" of obligatory rights, saying I have forced them "through a revolving door"'from which they "emerge, as it were, invigorated, looking like real rights". $\mathrm{He}$ even reads into my article the intimation that obligatory rights "are all but real". How does he justify such a construction? Levontin agrees that an obligatory right enjoys "universal" protection: "a vinculum juris" he writes, "is a norm for the parties but only a datum for strangers". So far we are in full agreement. So where do our paths diverge?

Levontin blames me for "focussing on the universal protection accorded to such rights, to the neglect of their content". True I did not elaborate on the content of obligatory rights. Why repeat what is common knowledge? It is all incorporated, unchanged, in my new classification. My only innovation has been to complete, with Levontin's blessing, the main element of the obligatory right, viz. the relationship between creditor and debtor, by the adjunction of a secondary element, the general duty of abstention.

Strangely enough it is in Levontin's Note that some strange deviations from well-established norms can be detected. Does Levontin seriously suggest that an obligatory right is terminated by "the obligor's conduct or misconduct" or by "his going insolvent or dying or by becoming insane etc."? Does he mean that in any such case the frustrated creditor may have. to surrender the security he holds and that the obligor's sureties are automatically released? Has my colleague lost sight of the legal remedies by which the creditor may seek to enforce his claim?

Indeed, in other passages Levontin does reflect upon the incidence of such remedies, but goes to the other extreme by exaggerating their importance. "What is a personal right", he asks, "if it is not the hypostasis of a prophecy that a personal decree can be obtained?" He thereby redefines a right in personam as a right protected by an action in personam, leading to a judg. 
ment in personam to be executed by an in personam process of law: and the same would apply mutatis mutandis to a right in rem. Unfortunately this apparently attractive dichotomy has been discarded as fallacious, arising from what Hohfeld called "linguistic contamination" (see supra p. 287, n. 1). Does not Levontin himself remind us that the remedy for wrongful interference with easements is an action in tort for private nuisance i.e., an action in personam? Easement itself would-Heaven forbid!-appear to be a personal right.

The definition of obligatory rights, at least within the relations between the parties is quite sufficient as it stands. Injecting into it the proposed reference to the kind of decree obtainable can only spoil it. Moreover, Levontin's criterion would leave "imperfect" rights (like a claim barred by limitation) or rights which cannot effectively be recovered in an action (e.g., when the whereabouts of the defendant cannot be traced), wholly beyond the scope of classification. Such rights may be of doubtful value, but their existence cannot be gainsaid.

\section{Ownership}

Why then, should Levontin object to the generalization of the notion of ownership to cover every type of property, including obligatory rights? Is that not the logical consequence of the universal protection given by law to "interests of all kinds"? And if so, is it fair to refer to it as a "turbulent process [that] hovers uncertainly" over the other rights, and to add that $I$ have "curiously proclaimed [it] to be neither fish nor fowl"?

Less sarcastically, but not more accurately, Levontin ascribes to me the idea-in order to reject it - that I treat ownership not only "as a class unto itself", but even as "more important than any... other". Are we not agreed that the whole importance of ownership is accessory? Does it not serve only as a bodyguard to the property for whose integrity it is responsible, by preventing undue interference from other persons?

Actually Levontin says the same; but, again, in such exaggerated terms that he destroys Ownership altogether. Thus he goes so far as denying that a thing may "belong" to anyone, "not even to its so-called owner". If I understand him well, he considers the right of ownership to be, "strictly" speaking, incompatible with any competing right with reference to the thing. This is in line with Roguin's contention that a landowner loses his ownership if he but allows some other person to pluck a single flower from his gardena statement of which he later repented. How then can Levontin berate me for placing Ownership on an all too "exalted" throne? This is an absurdity from which our statutory definition of ownership has remained immune. For all its other shortcomings, it has at least the merit to ascertain that none of the limitations placed upon ownership, whether by law or by agreement, has the effect of depriving the owner of the property "itself". Even if A's land is burdened with servitude in favour of $B$, leased to $C$ and mortgaged to $D$ 
far beyond its value, it is and remains A's property. Is A's ownership the "highest" or the "strongest" right? It would hardly be so by Levontin's standards: and yet no one in the world including $\mathrm{B}, \mathrm{C}$ or $\mathrm{D}$ would hesitate to refer to the land as "belonging to A". Juridically, the question of "who owns the land itself" is not otiose: it is both meaningful and remarkably simple; and everyday speech quite naturally identifies the property with the person of its "owner".

What surprises me is that Levontin takes such trouble to prove that ownership-which he also claims does not actually exist-is a right, some kind of right, and that to prove his point he even relies on the authority of our statutory definition of that right. Who had ever entertained any doubt on that score?

\section{The "Other" Real Rights}

Parallel to Dabin's reasoning, Levontin poses a dilemma to reject the very notion of real obligation. The owner of encumbered property, he maintains, only has a purely negative duty within the scope of the general duty of abstention. Alternatively, wherever his duty is (exceptionally) positive, it is a purely personal obligation created and recognized by law. Levontin does not seem in the least impressed by the numerous examples of real obligations cited in my article, such as those authorized by the Civil Code of Louisiana, the ancient feudal rights, the German Grundschuld, the Swiss rente foncière, Tsarist mortgages, or even in Israel the rule as to a security given for another person's debt. All these are simply ignored, as is the position, in Israel law, of the purchaser of property encumbered by lease or mortgage. The only illustration Levontin brings of a real right, is an easement and, in particular, a right of way, where indeed the duty of the servient owner is reduced to a minimum.

But even in that type of real right the dilemma falls flat. For, after having followed the discussion of A's "real right of way over land belonging to B" (something we had been told was inconceivable-or at least should be taken "with a grain of salt"?), let us now consider a merely personal, but otherwise identical, right of way. Surely there is nothing to prevent B from personally allowing $A$ to pass over his land. The question is, how shall we distinguish between these two parallel rights? And why should not B's personal obligation also be part of the general duty of abstention?

My theory offers the following solution: As long as B remains the owner of the land, there will indeed be no difference whatever as between $A$ and B: being mutually bound by a contractual tie, they are no strangers to each other.

The difference will only appear when the land is conveyed to a stranger, $\mathbf{C}$ (Maitland's test). In the case of a personal obligation, $\mathbf{C}$ being a third party is not bound by it. B's undertaking is for him no more than a datum which he may have to "respect" insofar as he has notice of it; otherwise he 
may ignore it, leaving A to seek his personal remedy, if any, from B. On the other hand, if B's obligation is "real"-making A's right of way similarly "real" - $\mathrm{C}$ will take B's place in the legal relationship originally created between $\Lambda$ and $B$. Whether $C$ knew of A's right or not, he will be bound to let him pass over his land, just as B was bound before the conveyance. In other words, the purchaser $\mathrm{C}$ is not a "stranger" vis-à-vis $\mathrm{A}$, nor does his duty have any connection with the general duty of abstention.

It goes without saying that the difference here described becomes still more conspicuous if the right of way is widened by the addition of some positive content (e.g., duty to build the road, to clean it or to keep it in a good state of repair). While a personal promise to the same effect may, as aforesaid, be sufficient ground for preventing a purchaser with notice from causing a breach of contract, such purchaser, whatever his knowledge, can never be compelled to perform any positive act-as he undoubtedly can be if the right of way is "real".

It is perfectly consonant with my theory to say-in Levontin's own termsthat "if an owner is liable as such, then it is his ownership that engages his liability [or, better, that engenders his obligation], not a transfer from a predecessor in title". This characteristic of "reality", however, will not become apparent until the encumbered property passes to a successor; and the latter obviously cannot be "saved" from the liability by the sole will of his predecessor: otherwise we would allow an indebtedness to be waived by ... the debtor!

Neither do I share Levontin's concern for the fate of a real right if the res passes into the hands of a bankrupt, a lunatic, a fugitive or a diplomat. There is no lack of procedural devices to provide for the representation of a deficient party; and should these prove ineffective, the frustrated owner of the real right will probably join the chorus of disgruntled litigants whose good right, whatever be the class to which it belongs, has for some cause not been recognized and sanctioned. But, as matters stand, there is no reason to apprehend that in my system real rights "come out enfeebled, somewhat sheepishly, as obligatory claims".

S. G. 